\title{
Perkembangan Kajian Hadis Ulama Banjar: Analisis Genealogi Intelektual dan Pengaruhnya Terhadap Corak Kajian Hadis
}

\author{
Hanafi $^{1}$
}

\begin{abstract}
Since the $16^{\text {th }}$ century, the Middle-East had become a destination for scholars of Nusantara who seeking for knowledge. The Middle-East scholars' network had an important role for developing a various number of Islamic intellectual tradition in Nusantara. It happened to Banjarese society as well. In the process of knowledge transmission, ulama Banjar got so much influenced by the Islamic thoughts which came from the MiddleEast, including theology, fiqh, mysticism, and hadith. This article aimed to identify how much influence the Middle-East scholars had given to intellectual tradition development of ulama Banjar scholars in the study of hadith. The effect of the Middle-East scholars' influence can be seen in the intellectual science and manuscripts of the study of hadith which are produced by the ulama Banjar. The method of this research is reading primary sources such as hadith manuscripts which are written by them, and furthermore, reading their sanad pedigree and ijazah of hadith which connected to the Middle-East hadith scholars. The reading of those data proved that the ulama Banjar hadith scientific had a connection with the authoritative scholars of hadith in the Middle-East. The ulama Banjar who were taken as the object of this research are the scholars who came from Banjarese tribe and had written manuscripts of hadith, or had the study of hadith written whether in Arabic or Malay. According to the standard used, the researcher found seven scholars whom categorized as the research objects, they are Muhammad Arsyad al-Banjari, Muhammad Kasyful Anwar, Muhammad Anang Sya'rani Arif, Abdul Wahid, Muhammad Syukeri Unus, Fahmi Zamzam, and Muhammad Nurdin Marbu.
\end{abstract}

${ }^{1}$ Pengajar di SMA Global Islamic Boarding School Banjarmasin. E-mail: hanafirai71@gmail.com 


\begin{abstract}
Abstrak
Timur Tengah menjadi destinasi keilmuan bagi para Ulama Nusantara sejak abad ke-16. Jaringan ulama Timur Tengah mempunyai andil besar dalam mengembangkan aneka ragam tradisi intelektual keislaman di Nusantara. Begitu juga yang terjadi di masyarakat Banjar. Dalam proses transmisi keilmuan, ulama Banjar banyak sekali terpengaruhi oleh pemikiranpemikiran keislaman yang berasal dari sana, termasuk dalam pemikiran kalam, fikih, tasawuf, dan kajian hadis. Dalam artikel ini akan membuktikan sejauh mana pengaruh ulama Timur Tengah terhadap pengembangan tradisi intelektual ulama Banjar dalam kajian hadis. Metode penelitian dalam artikel ini adalah dengan cara membaca sumber-sumber primer, berupa naskahnaskah hadis karya ulama Banjar, kemudian silsilah sanad dan ijazah hadis mereka yang terhubung dengan ulama hadis di Timur Tengah. Pembacaan terhadap sanad dan ijazah tersebut akan membuktikan bahwa keilmuan hadis mereka terhubung kepada para ulama hadis yang otoritatif. Ulama Banjar yang masuk sebagai objek penelitian disini adalah ulama yang berasal dari suku Banjar, mempunyai naskah di bidang hadis, atau kajian hadis yang berbahasa Arab atau bahasa Arab Melayu. Dari standarisasi yang digunakan tersebut, ditemukan tujuh ulama yang masuk sebagai objek penelitian, Muhammad Arsyad al-Banjari, Muhammad Kasyful Anwar, Muhammad Anang Sya'rani Arif, Abdul Wahid, Muhammad Syukeri Unus, Fahmi Zamzam, dan Muhammad Nurdin Marbu.
\end{abstract}

Keywords: Ulama Banjar, Jaringan Ulama, Kajian Hadis, Timur Tengah, Banjar.

\title{
Pendahuluan
}

Perjalanan sejarah kompilasi dan kodifikasi hadis telah melewati serangkaian fase historis yang panjang dan rumit. Diawali dengan penyampaian hadis dari Nabi dan selanjutnya diterima oleh para sahabat yang direkam dalam bentuk hafalan, ada pula yang dicatat dalam bentuk dokumen tertulis. Kemudian para sahabat menyampaikan hadis kepada generasi tabi'in yang sebagiannya juga telah direkam secara tertulis, sampai pada akhirnya pada 
penghujung abad I $\mathrm{H}$ atau awal abad II $\mathrm{H}$ mulai ditempuh kodifikasi hadis secara resmi dan publik. ${ }^{2}$

Memasuki abad ke II H sampai abad VII H, sejarah kodifikasi hadis mengalami kemajuan yang sangat signifikan. Jamila Shaukat mencatat ada beberapa jenis pola penulisan kitab hadis yang berbeda dari segi metode dan berbeda pula dari penamaan, ada yang disebut dengan sahifah, risalah, juz, arba'in, mu'jam, amāil, aträ́, jami', sunan, musannaf, musnad. ${ }^{3}$ Akan tetapi, masa keemasan penulisan kitab hadis bisa dikatakan terjadi ketika tersusunya enam kompilasi hadis utama, yang kemudian lebih populer dengan istilah (alKutub al-Sittah). ${ }^{4}$

Kendati kodifikasi hadis mengalami masa keemasan pasca lahirnya enam kitab induk tersebut, hal itu bukan berarti tanpa meninggalkan perdebatan di kalangan masyarakat akademik. Dari segi lintas aliran, enam kitab induk itu hanya diakui kelompok ạ̣l al-Sunnah wa al-Jamā'ah. Sementara bagi kaum Syi'ah penyusunan hadis berdasarkan bab telah diawali oleh Abū Rāfi', dan upaya tersebut mencapai puncaknya pada abad ke IV dan V H ketika berhasil disusun Empat Kompilasi Hadis Utama (al-Kutub al-Arba'ah). ${ }^{5}$ Dari segi posisinya, enam kitab hadis utama (al-Kutub al-Sittah) masih diperdebatkan. Perdebatan itu terkait persoalan kedudukan kitab sahị ibn Majah yang keenam. Ibn Tăhir al-Maqdisi menyatakan bahwa sahịh ibn Majah adalah kitab keenam dalam enam kitab hadis utama tersebut. Pendapat al-Maqdisi ini sepertinya lebih kuat dibandingkan dengan pendapat-pendapat yang lainnya seperti yang diungkap oleh Fatkhi dalam risetnya. ${ }^{6}$ Bahkan Kitab Jami' al-Saḥih al-Bukharī tidak luput dari kritik para akademisi, tokoh orientalis seperti Norman Calder

${ }^{2}$ Muhammad ibn Mațar al-Zahrānī, Tadwìn al-Sunnah al-Nabawiyah, (Madīnah: Dār al-Khudayrī, 1998) 83-85. Lihat juga dalam Subhị al-Șălih, 'Ulum al-Hadìth wa Muștalahuhu (Beirut: Dar al-'ilm li al-Malayin, 1988), 44-45.

${ }^{3}$ Jamila Shaukat, "Classification of Ḩadīth Literature", Islamic Studies, Vol. 24. No. 3 (1985), 358-380. Diakses dari http://www.jstor.org/stable/20839730 pada 10-06$\underline{2015}$.

4 Enam kitab induk tersebut adalah: Jami' al-Sahīh al-Bukhārīi(194-256 H), Jami' al-Sahịh Muslim (204-256 H), Sunan Abü Däud (202-275 H), Sunan al-Tirmidhi (209-279 H), Sunan al-Nasai (215-303 H), Sunan Ibn Majah (209-273 H) . Lihat dalam Rif' at Fauzi 'Abd al-Mutallib, Manahij al-Muhaddithīn al-Usus wa al-Tatbìiq (Kairo: Dār al-Salam, 2008), 65-85.

${ }^{5}$ Saifuddin, Arus Tradisi Tadwin Hadis dan Historigrafi Islam: Kajian Lintas Aliran (Yogyakarta: Pustaka Pelajar, 2011), 92-94. Lihat juga dalam: Mạ̣mūd Abū Rayyah, Aḍ̛̂a' ala al-Sunnah, 272.

${ }^{6}$ Kontribusi Ibn Mājah dalam bidang hadis-hadis fiqh menjadikan kompilasi kitab hadisnya lebih layak masuk dalam jajaran Enam Kitab Hadis Utama. Lihat dalam Rifqi Muhammad Fatkhi,"Hadith dalam Hegemoni Fiqh: Membandingkan Sahị Ibn Hibban dan Sunan Ibn Majah", Jurnal Quhas, Vol. 1, No.1. (2011), 147-157. 
yang dikutip oleh Christoper Melchert yang mempertanyakan kualitas kitab Tarikh al-Kabīr sebagai referensi al-Bukhäri dalam proses seleksi para rawi. ${ }^{7}$ Kritikan yang senada juga dilontarkan oleh ulama Islam lainnya seperti Nașiruddin al-Albāni (1333-1420 H) yang menyatakan bahwa dalam Jami' alSahīh Muslim banyak sekali hadis-hadis yang lemah. ${ }^{8}$

Dalam perjalanannya di Nusantara, Hadis tidak terlalu mendapatkan fokus yang begitu banyak dari kalangan ulama Nusantara kala itu. Hal ini terlihat sebagaimana yang diungkap oleh Muhajirin dalam penelitiannya bahwa "ketidakpesatan" tersebut tidak bisa dilepaskan dari faktor historisnya. ${ }^{9}$ Dia menyebutkan secara historis memang Islam Indonesia pada mulanya menganut paham bersifat sufistik. ${ }^{10}$ Sehingga tidak mengherankan jika pada masa awalawal Islam di Nusantara banyak literatur-literatur sufi yang beredar di masyarakat lokal. Begitupula dengan materi fikih yang senantiasa disajikan kepada masyarakat lokal yang berujung kepada taqlid dengan empat imam besar-terutama al-Shāfi ‘' $\bar{i}$. Kajian tasawuf dan fikih pada masa awal Islam Nusantara ini terus berkembang dan diajarkan kepada generasi penerusnya, imbasnya ungkap Azyumardi Azra adalah kedua ajaran tersebut berkembang menjadi sebuah doktrin yang terpatri tanpa harus dikaji dan diolah kembali. ${ }^{11}$

7 Christopher Melchert, "Bukhāī and Early Hadith Criticism", Journal of the America Oriental Society, Vol. 121, No.1 (2001), 7-15. http://www.jstor.org/stable/606725, diakses pada tanggal 10-6-2015.

${ }^{8}$ Kamaruddin Amin, "Nāṣiruddīn al-Albānī on Muslim's Șahịị: A Critical Study of His Method" Journal Islamic Law and Society, Vol. 11, No. 2 (2004), 149-170. http://www.jstor.org/stable/3399302, diakses pada tanggal 10-6-2015.

9 Secara historis perdebatan masyarakat akademik mengenai awal masuknya Islam ke Nusantara masih belum selesai dan seakan-akan masih menggantung. Menurut Azyumardi Azra terdapat diskusi dan perdebatan panjang di antara para ahli mengenai tiga masalah pokok menyangkut kedatangan Islam di Nusantara, yaitu tempat asal kedatangan Islam, para pembawanya, dan waktu kedatangannya. Namun menurut Azra, teori yang menyebut bahwa kedatangan Islam pada abad ke-13 $\mathrm{M}$ lebih dapat dipertanggungjawabkan. Perdebatan ini dikupas secara luas dalam: Azyumardi Azra, Jaringan Ulama Timur Tengah dan Kepulauan Nusantara Abad XVII \& XVIII: Akar Pembaharuan Islam Indonesia (Jakarta: Kencana, 2007), 2-46. Namun terlepas dari perdebatan itu semua, Islam menyebar ke berbagai pelosok Nusantara, sehingga secara mengejutkan -meminjam istilah Syafii Maarif- Islam tampil sebagai "pemenang" dari segi kuantitas pemeluknya di Nusantara dengan menggantikan agama yang sudah lama berkuasa pada masa itu, yaitu Hindu dan Budha. Lihat dalam: Ahmad Syafii Maarif, Islam dalam Bingkai Keindonesian dan Kemanusiaan (Bandung: Mizan, 2015), 46.

${ }^{10}$ Muhajirin, Transmisi Hadis di Nusantara: Peran Ulama Hadis Muhammad Mahfüdz al-Tarmasì, Disertasi SPs UIN Jakarta, 2009, 1.

11 Azyumardi Azra, Historiografi Islam Kontemporer, Wacana Aktualitas dan Aktor Sejarah (Jakarta: Gramedia Pustaka Utama, 2002), 120. 
Geliat intelektual ulama Nusantara tersebut nampak terlihat dari keterlibatan mereka yang sedang menuntut ilmu yang berpusat di Haramain (Mekah dan Madinah). Perintis ulama-ulama tersebut antara lain diwakili oleh Nür al-Dīn al-Raniri (w.1068 H/1658 M), Abd al-Rauf al-Sinkili (w.10241105/1615-1693 M), Muhammad Yūuf al-Maqassari (w.1030-1111/1629-1699 M), Muhammad Arsyad al-Banjari (1710-1812 M), dan lain sebagainya. ${ }^{12}$ Dari Jaringan ulama ini ada di antaranya yang menghasilkan karya di bidang hadis seperti al-Raniri dengan karyanya (Hidayah al-Habīb fi al-Targhīb wa al-

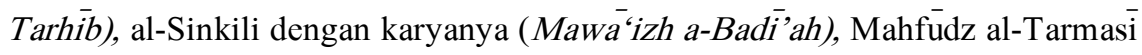
dengan karyanya (Manhaj Dzawi al-Nazr), Nawawi al-Bantani dengan karyanya (Syarh Tanqīh al-Qaul). ${ }^{13}$ Selebihnya hadis masih bersifat antologi di berbagai karya ulama di Nusantara seperti fiqh, tasawuf dan teologi.

Dalam konteks Kalimantan Selatan, perkembangan hadis pada masa Islam menjadi agama resmi kerajaan Banjar juga tidak begitu terlihat. Kendati menjadi agama resmi, menurut Azyumardi Azra kepatuhan masyarakat Banjar terhadap Islam kala itu tidak lebih dari pengucapan syahādah saja. ${ }^{14}$ Adalah Muhammad Arsyad al-Banjari (1710-1812 M) yang disebut Azra sebagai tokoh pembaharuan Islam di Kalimantan Selatan yang begitu berjasa dalam proses perubahan sikap keberagamaan itu. Karya-karya seperti sabil al-Muhtadin dan Tuhfah al-Răghibin menjadi pedoman sekaligus referensi berislam yang sangat penting kala itu. Lebih jelasnya Mujiburrahman menyebut bahwa perannya begitu penting dalam mengubah pola keberagamaan masyarakat yang dulunya masih terpengaruh dengan budaya masa lalu, seperti menyanggar, mambuang pasilih dan tradisi yang sangat kental dengan nuansa kesyirikannya perlahan dihilangkan dengan cara pendekatan yang efektif. ${ }^{15}$ Oleh karenanya, karyakarya tulis Arsyad al-Banjari lebih dominan tentang kajian fiqh, tauhid dan tasawuf. Sehingga karyanya di bidang hadis murni hampir bisa dikatakan tidak ada. Hadis-hadis hanya menjadi fragmen dalam kitab-kitab fiqh, tauhid dan tasawuf, tidak dibahas secara mandiri dan terpisah.

Kendati karya-karya Muhammad Arsyad al-Banjari bukanlah karya hadis murni, tetapi muatan-muatan hadis di dalamnya guna menopang argumen yang ia kemukakan begitu penting untuk dilihat guna menemukan model pemahaman

${ }^{13}$ Hasan Su'aidi, "Jaringan Ulama Hadis Indonesia", Jurnal Penelitian, Vol.5, No.2 (2008), 3-8.

${ }^{14}$ Azyumardi Azra, Jaringan Ulama, 315-318.

${ }^{15}$ Mujiburrahman, "Islamic Theological Text and Context in Banjarese Society: An Overview of the Existing Studies," South East Asian Studies (SEAS), Voi. 3, No. 3 (2014), 611-615. 
hadis yang ia kembangkan. Tekstual atau kontekstual dalam memposisikan hadis kala bersinggungan dengan budaya serta tradisi masyarakat Banjar kala itu yang masih didominasi paham animisme dan dinamisme kendati sudah berislam.

Karya hadis murni dari ulama lokal yang ada di Masyarakat Banjar (yang kemudian disebut dengan istilah Ulama Banjari) sebenarnya baru dimulai yang menurut rekaman sejarah orang pertama di wilayah Banjar yang menulis karya di bidang hadis adalah Muhammad Kasyful Anwar al-Banjari (1887-1940 M) dengan judul al-Tibyān al-Rawī; Sharh Arba 'in al-Nawawi. ${ }^{16}$ Tradisi penulisan kitab hadis mulai terlihat pasca Kasyful Anwar al-Banjari dengan hadirnya beberapa kitab karya Ulama Banjarī seperti yang ditulis oleh Muhammad Sya'rani 'Arif al-Banjari (1914-1969) dengan judul Hidayah al-Zamān min

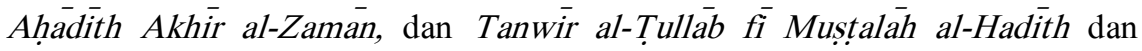
Tanwì al-Tullab untuk kajian dirayah. Keilmuan Sya'rani 'Arif dalam bidang hadis sangat populer ketika dia berada di Mekkah kala menuntut ilmu, sehingga dengan kepakarannya di bidang hadis, dia mendapat gelar mufassir dan muhaddith. ${ }^{17}$

Generasi Ulama Banjari dalam pakar hadis kiranya tidak putus sampai di situ. Adalah Muhammad Syukeri Unus al-Banjari (1947- masih hidup) yang melanjutkan tradisi penulisan kitab hadis. Karyanya di bidang hadis adalah 40 Hadis Kelebihan Ilmu dan Ulama (Hadith al-Arba'in fì al-'Ilm), dan Dalì alTăalibìn fì Asma al-Rijal tentang 'ilm hadith. Syukeri Unus al-Banjari adalah ulama yang terkenal memiliki isnad keilmuan yang banyak. ${ }^{18}$

Tradisi intelektual ulama Banjar di bidang hadis terus berlanjut. Ahmad Fahmi Zamzam al-Nadwi al-Banjari (1959-masih hidup) yang banyak menulis karya di bidang hadis. Karya-karyanya adalah 40 Hadis Peristiwa Akhir Zaman, 40 Hadis Akhlak Mulia, 40 Hadis Penawar Hati, dan 40 Hadis Kiamat Hampir Tiba. $^{19}$

Hal yang sama juga dilakukan oleh ulama Banjar yang lain, adalah Nurdin Marbu al-Makkī al-Banjarī (1960-masih hidup) ulama yang produktif dalam menulis, tulisan-tulisan beliau berbentuk tahqiq, ta'liq terhadap kitab-

${ }^{16}$ Ahmad Taufik Mubarak, "Tuan Guru Haji Kasyful Anwar dan Kiprahnya di Pondok Pesantren Darussalam Martapura”, Jurnal Studi Islam Kalimantan, Vol. 8, No. 2 (2009), 151-154.

${ }^{17}$ Saifuddin, Dzikri Nirwana, Bashori, "Peta Kajian Hadis Ulama Banjar”, 27.

${ }^{18}$ Informasi ini penulis dapatkan dari karya hadisnya, lihat dalam: Muhammad Syukeri Unus, Dalìl al-Ṭalibìn fi Ma'rifat Asma al-Hadith (Martapura: Majelis Taklim Sabil al-Anwar al-Mubarak, t.th), 1-29

19 Ahmad Makki, Profil dan Kinerja Anak Banua: Apa \& Siapa dari Utara (Banjarmasin: MUI, 2011), 65-69. 
kitab klasik, dan ada juga yang tulisan murni darinya. Karya-karya di bidang hadis sangat banyak, sebagaimana yang disebut nantinya dalam data primer.

Ulama Banjar yang terakhir yang terdeteksi mempunyai karya di bidang kajian hadis Abdul Wahid al-Banjari (1949-masih hidup). Ulama yang lama menimba ilmu di Mekkah ini menulis karya hadis dengan bahasa arab murni dengan judul lengkap Tadhkirah al-Lisān min al-Ahādith al-Mawḍu'at 'alā Sayyid al-Bashar. Sesuai dengan nama kitabnya, fokus kajian kirab ini adalah ' ilm al-hadith tentang hadis-hadis mawḍu' ${ }^{20}$

Secara garis besar permasalahan yang akan dijawab dalam penelitian ini adalah bagaimana pengaruh genealogi intelekutal dari ulama Timur Tengah terhadap ulama Banjar dalam kajian hadis. Untuk menjawab pertanyaan penelitian, sebagaimana yang dijelaskan Moleong diperlukan sumber data, baik primer maupun sekunder. ${ }^{21}$

Ulama Banjar yang dijadikan sumber utama dalam penelitian ini menggunakan beberapa indikator-indikator. (1) karya tersebut konsentrasinya di bidang hadis, bisa berbentuk ilmu hadis, atau hadisnya saja. (2) karya-karya awal Islam di masyarakat Banjar, yang diwakili oleh Arsyad al-Banjari, (3) karya tersebut berbentuk bahasa Arab Murni, atau Arab Melayu. (4) ulama tersebut adalah yang kesukuannya berasal dari masyarakat Banjar.

Karya hadis Ulama Banjar tersebut kemudian menjadi penting untuk dilihat sejauhmana pengaruh corak Timur Tengah terhadap pola pengkajian hadis.

Berikut nama ulama Banjar dan karya-karyanya yang menjadi sumber primer dalam penelitian ini:

1. Muhammad Arsyād al-Banjarī, dengan karya Sabīl al-Muhtadīn, dan Tuḥfah al-Raghibīn.

2. Muhammad Kasyful Anwar al-Banjari, karya dibidang hadisnya: al-Tabyīn al-Rawī; Sharh 'Arba'in al-Nawawì

3. Muhammad Sya'rani 'Arif al-Banjari, karyanya: Hidāyah al-Zamān min

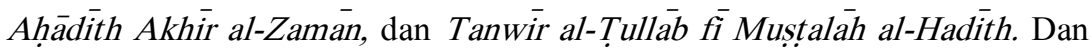
Tanwir al-Tulläb untuk 'ilm hadith.

4. Muhammad Syukeri Unus al-Banjari, karyanya 40 Hadis Kelebihan Ilmu dan Ulama (Hadith al- 'Arba'ín fì al-'Ilm), dan Dalil al-Ṭalibin fí Asma al-Rijal.

5. Abdul Wahid al-Banjari dengan karya hadisnya Tazkirah al-Lisan.

20 Informasi ini peneliti dapatkan dari karya beliau, lihat Abdul Wahid, Tadhkirah al-Lisān min al-Ahāōith al-Maựu' at 'alā Sayyid al-Bashar (Barabai, al-Syifā, 2012), $x$.

${ }^{21}$ Lexy J. Moleong, Metodologi Penelitian Kualitatif (Bandung: PT Remaja Rosda Karya, 2014), 248-257. 
6. Fahmi Zamzam al-Nadwì al-Banjari dengan karyanya: 40 Hadis Peristiwa Akhir Zaman, 40 Hadis Akhlak Mulia, 40 Hadis Penawar Hati, dan 40 Hadis Kiamat Hampir Tiba.

7. Muhammad Nūr al-din Marbū al-Makkī al-Banjarî, dengan karyanya di bidang hadis:

a. Adab al-Mushāfaḥah,

b. al-'Ibar bi Ba'ḍ Mu'jizāt Khayr al-Bashar,

c. al-Ahādīth al-Musalsalah,

d. al-Amr bi al-Ma'rüf wa al-Nahy al-Munkar fi Kitāb wa al-Sunnah

e. al-Iqtibās min Ahāōith 'Abd ibn 'Abbās.

f. al-Kawākīb al-Dūrī min Hadīth Abī Sa'īd al-Khudrī.

g. al-Maskh fī Kitāb wa al-Sunnah.

h. Al-Riddah fī Kitāb wa al-Sunnah

i. al-Yaqīn. Asmā' al-Thālib bi ba'dh Aḥādīth Sayyidinā 'Alī ibn Abī Tālib.

j. Bingkisan Perpisahan 40 Mutiara Hadis dari 40 Buah Kitab.

k. Fayḍ al-Ilāh min Ahāēìth al-Jabīr ibn 'Abd Allāh.

1. Hā’ulā’ fì Șahābah Malā'ikah al-Kirām 'alayhim al-Salām.

m. al-Qiyāmah.

n. Hā'ulā' Lahum Buyūt wa Qushūr fĩ al-Jannah.

o. Isțilā‘ Arā' al-'Ulamā Hawl Qawluh saw (Lan Yuflih Qaum wallaw Amrahum Imra'ah).

p. Majāl al-Ṣadaqah fī al-Islām.

q. Makānah al-'Ilm wa al-'Ulamā wa Adab Ṭālib al-'Ilm.

Jaringan Timur Tengah tetap menunjukkan kontribusinya bagi pengembangan intelektual Islam. Penyebutan istilah Jaringan Timur Tengah lebih adil, ketimbang dengan istilah Jaringan Haramayn yang fokus di Mekkah dan Madinah saja. Sebab dari pembacaan terhadap 'journey for seeking knowledge' ulama Banjar, mereka tidak saja berada di Mekkah dan Madinah, tapi juga ke Mesir.

Mekkah dan Madinah atau yang lebih dikenal dengan 'tanah haram' atau Haramayn menempati posisi yang sangat penting dalam Islam. Mekkah mempunyai ka'bah tempat orang shalat setiap saat, sedangkan di Madinah ada makan Nabi saw dan para Sahabat. Kondisi sosial politik di Haramayn pada kurun waktu abad ke-16 masehi yang semakin membaik, ditambah dengan 'faḍ̄'il' yang dimiliknya membuat orang-orang semakin tertarik untuk migrasi ke Haramayn. Banyaknya imigran yang berdatangan ini sebenarnya beragam 
motifnya. John O. Voll sebagaimana yang dikutip Azyumardi Azra menjelaskan setidaknya ada tiga motif banyaknya imigran berdatangan; (1) orang-orang yang awalnya pergi untuk berhaji, kemudian dengan berbagai alasan merasa nyaman tinggal di sana dan menetap. (2) para ulama dari berbagai daerah Islam yang menetap kesana untuk ikut dalam wacana keilmuan. (3) para pelajar dari berbagai belahan dunia yang ingin menuntut ilmu dengan para ulama di Haramayn. $^{22}$

Dari hasil pembacaan terhadap beberapa catatan tentang biografi ulamaulama al-Banjari, generasi-generasi yang belajar di Timur Tengah dapat diklasifikasikan menjadi tiga generasi (1) Generasi pertama; atau disebut pula dengan fase pembentukan jaringan (2) Generasi kedua; fase penguatan jaringan, (3) Generasi ketiga; fase pelestarian jaringan.

\section{Generasi Pertama: Fase Pembentukan Jaringan Ulama "Timur Tengah-Banjar"}

Tradisi rihlat 'ilmiyyah ulama Banjar ke Haramayn mulai mengakar saat pertama kali Arsyad al-Banjari (w. 1812 M) diberikan beasiswa pendidikan oleh kerajaan Banjar yang dipimpin Sultan Tahlī Allāh (w. 1745 M). Menurut Abu Daudi beasiswa yang diberikan tidak tanggung-tanggung, jumlahnya sangat besar. Semua keperluan selama studi di sana semua terjamin. Rumah disediakan di kawasan Syamiah yang terkenal dengan nama Barhat Banjar. ${ }^{23}$ Belum ditemukan apa yang mendorong kesultanan Banjar pada masa itu untuk memberikan besiswa tersebut. Namun dapat dipastikan bahwa bantuan pendidikan kepada Arsyad al-Banjari merupakan langkah yang strategis dalam perkembangan Islam selanjutnya di masyarakat Banjar. Sebab menurut Azra kepatuhan masyarakat banjar terhadap Islam sangat minim dan tidak lebih dari pengucapan "syahadah" saja. ${ }^{24}$

Selama studi di sana, Arsyad al-Banjari bertemu dan belajar dengan guru-guru yang mempunyai otoritas di masing-masing bidang. Semisal, 'Ațā' Allah al-Mișrí, Muhammad Ibn Sulaiman al-Kurdi, Muhammad al-Jauhari, Ahmad ibn 'Abd Mum‘in al-Damanhuri, Ibrahīm al-Ra'-is. Menurut Azra, dari al-Ra' is lah Syeikh Arsyad mempelajari 'ilm al-falak (astronomi), bidang yang menjadikannya salah seorang ahli yang paling menonjol dalam disiplin ilmu ini

${ }^{22}$ Azyumardi Azra, Jaringan Ulama Timur Tengah dan Kepulauan Nusantara Abad XVII \& XVIII: Akar Pembaharuan Islam Indonesia (Jakarta: Prenadia Group, 2013), 74-76.

${ }^{23}$ Abu Daudi, Maulana Syeikh Muhammad Arsyad al-Banjari (Tuan Haji Besar) (Martapura: Yayasan Islam dalam Pagar, 2003). 47.

24 Azyumardi Azra, Jaringan Ulama Timur Tengah dan Kepulauan Nusantara Abad XVII \& XVIII, 328. 
di antara para Melayu-Indonesia lainnya. ${ }^{25}$ Dalam bidang hadis ia mendapatkan otoritas isnad dari gurunya yang bernama Sālim ibn 'Abd Allah al-Bașri alMakki $(1160 \mathrm{H}){ }^{26}$

Dari data sanad yang ditemukan, Syeikh Salim adalah seorang pakar hadis di masanya. Ia banyak belajar dari ayahnya sendiri yaitu Syeikh 'Abd Allah ibn Sālim. Ayahnya mempunyai sebuah kitab susunan skema sanad hadis yang didapat dari ulama-ulama lainnya, kitab itu diberi judul al-Imdâd fi Ma'rifat 'Uluw al-Hadith. Dalam pengantar kitab ini, Syeikh 'Abd Allah menjelaskan bahwa Islam dianugerahi keistimewaan berupa sanad yang bisa menghubungkan muslim dengan Nabinya. Agar sistem dan skema sanad dari satu generasi tidak hilang, ia menghimpunnya dalam sebuah kitab tersebut. ${ }^{27}$ Lebih lanjut John O. Voll mencatat bahwa 'Abd Allah ibn Salim adalah guru hadis yang terpenting di Haramayn pada abad ke-18 M yang mengajar di mesjid al-Haram. Metode pembelajarannya dengan cara pemberian dokumen sanad kitab-kitab hadis yang mu'tabarah. ${ }^{28}$ Menurut Eerik Dickinson, sistem sanad dalam pembelajaran hadis merupakan sebuah garansi bahwa ucapan tersebut memang dari Nabi, dan bentuknya pun berbeda-beda. Ada sanad yang panjang, ada pula yang pendek. ${ }^{29}$

Guru Arsyad al-Banjarī dalam bidang hadis ini, Syeikh Sālim ibn 'Abd Allah terkenal sebagai muhaddith di Haramayn. Dia juga seorang pakar sanad hadis yang kemudian dia tulis menjadi sebuah kitab yang bernama Imdâd bi Ma'rifat 'Uluw al-Hadith yang merupakan ringkasan dari karya ayahnya. ${ }^{30}$

Model pengkajian hadis yang dikembangkan oleh Arsyad al-Banjari terkesan masih 'mengekor' dengan disiplin ilmu-ilmu keislaman lainnya. Indikasi ini setidaknya dapat terlihat dari dua model kitab yang ditulis oleh

25 Azyumardi Azra, Jaringan Ulama Timur Tengah dan Kepulauan Nusantara, 329.

${ }^{26}$ Wan Mohd Shagir Abdullah, Syeikh Muhammad Arsyad al-Banjarī Pengarang Sabī al-Muhtadin (Kuala Lumpur: Khazanah Fathaniyah, 1990), 18-19.

27 'Abd Allah ibn Sālim al-Makkī, al-Imdād fì Ma 'rifat 'Uluw al-Hadith (Riyad: Dār al-Tauhìid, t.th), 53-54.

28 John O. Voll, “ "Abd Allah ibn Salim al-Basrī and 18th Century Hadith Scholarship", Journal Die Welt des Islams, New Series, Vol. 42, Issue 3, Arabic Literature and IslamicScholarship in the 17th/18th Century: Topics and Biographies (2002), 362-365. Diakses melalui http//www.jstor.org/stable/1571419 pada tanggal 3 Maret 2016.

29 Eerik Dickinson, "Ibn al-Șalāh al-Shahrazūrī and the Isnād", Journal of the American Oriental Society, Vo. 122, No. 3 (Jul,- Sep., 2002), 505. Diakses melalui http://www.jstor.org/stable/3087517 pada tanggal 15 September 2015.

30 Riḍo ibn Muhammad, Musnid al-Hijāa. Makalah di Universitas King Abdul Aziz Jeddah, Fakultas Adab dan Humaniora, 34-35. 
Arsyad al-Banjari, yaitu Tuhfat al-Raghibin di bidang tauhid, dan kitab sabī alMuhtadin dalam bidang fikih. Dalam kitab Tuhfat al-Răghibīn secara jelas disebutkan bahwa Arsyad al-Banjari mengomentari tradisi-tradisi masyarakat dan persoalan keimanan lainnya berdasarkan dengan landasan al-Qur'an dan hadis. ${ }^{31}$ Ada sekitar 30 potong ayat dan 20 hadis yang digunakan oleh Syeikh Arsyad dalam kitab tersebut dan ditambah dengan beberapa refensi ulama klasik sebelumnya. $^{32}$

Kitab Tuhfat al-Rāghibīn yang mengutip dari beberapa hadis-hadis, kemudian diberikan penjelasannya dalam kitab ini memiliki beberapa fungsi, setidaknya ada dua:

\section{1) Sebagai Dalil Menjelaskan Tentang Akidah dan Kelompok-kelompok yang Menyesatkan}

Arsyad al-Banjari sedari awal dakwahnya memang ingin memperkuat dan mengokohkan akidah masyarakat Islam Banjar. Menurutnya, aliran teologi yang dianggap selamat hanya ada satu, yaitu aliran ạ̣l al-Sunnah wa aljamā'ah. Untuk memperkuat itu, ia melegitimasi pendapatnya tersebut dengan mencantumkan hadis yang ditulis dalam kitab Tuhfat al-Răghibin $:^{33}$

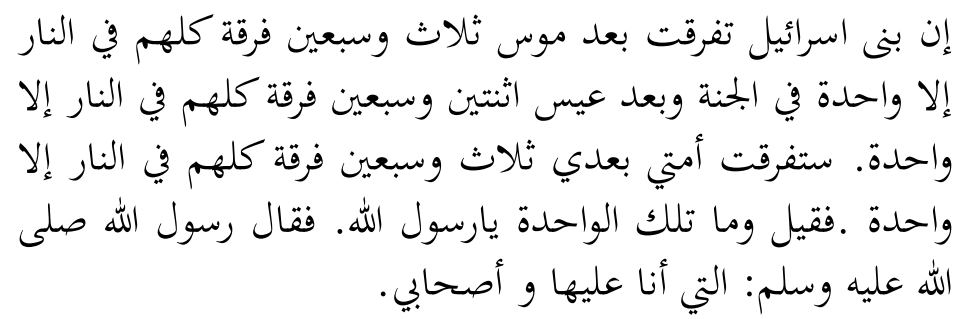

Artinya: Kaum Bani Israil berpecah belah sesudah nabi Musa menjadi tujuh puluh tiga golongan, semuanya masuk neraka kecuali satu golongan yang masuk surga. Dan sesudah Nabi Isa berpecah belah umatnya menjadi tujuh puluh dua golongan semuanya masuk neraka melainkan satu golongan yang akan masuk surga. Selagi akan berpecah belah umatku sesudahku menjadi tujuh puluh tiga golongan semuanya masuk neraka kecuali satu golongan yang masuk surga. Rasulullah saw ditanya:

${ }^{31}$ Muhammad Aryad al-Banjari, Tuhfah al-Raghibin, 53-54.

${ }^{32}$ Untuk lebih jelasnya lihat penelitian M. Rusydi, "Ideologi dan Epistimologi Kitab Tuhfah al-Rāghibìn Karya Muhammad Arshad al-Banjari”, Jurnal Islamica, Vol. 8, No. 2 (Maret, 2014), 490-493.

${ }_{33}^{33}$ Muhammad Arsyad al-Banjari, Tuhfat al-Raghibìn fì Bayān Haqīqat İmān alMu'minīn (Martapura: Dār al-Shākirin, t.th), 21. 
“siapa yang satu golongan itu ya Rasulullah?”, Rasulullah saw menjawab adalah (masa) aku ini dan semua sahabatku.

Menurut Syeikh Arsyad, pemahaman hadis ini adalah bahwa orang-orang yang mengikuti Nabi saw dan para sahabat itu dinamakan kelompok ahl alSunnah wa al-Jamā'ah. Lebih lanjut ia menjelaskan "Syahdan adalah jalan aḥl al-Sunnah wa al-Jamā'ah itu antara mazhab Jabariyah dan Qadariyah, dan

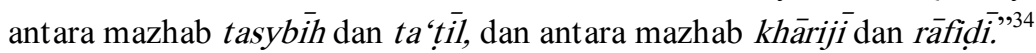

Pemahaman hadis yang ditulis Syeikh Arsyad dalam kitab tersebut tampaknya merupakan pemahaman hadis yang eksklusif (tertutup). Sebab menurutnya golongan-golongan yang ada dalam Islam ini semuanya masuk neraka disebabkan mereka tidak mengikuti Nabi dan para sahabatnya, kecuali ahl al-sunnah wa al-jama'ah yang teologinya al-Ash'ari. Secara lebih lanjut Arsyad al-Banjari menjelaskan panjang lebar tentang berbagai macam golongan dalam Islam yang menurutnya masuk neraka, mulai dari rafị̣iyyah, murjiah, khawarif, dan mu'tazilah. Penjelasan itu disertai dengan ajaran dan konsepnya yang menurut Arsyad al-Banjari adalah sesat. ${ }^{35}$

Pemahaman seperti ini menurut penulis sangat tendensius yang bisa menggiring kepada klaim sesat-menyesatkan antar sesama komunitas muslim yang bisa mencederai sendi-sendi kerukunan dalam internal agama.

\section{2) Sebagai dalil untuk melakukan pembaharuan terhadap tradisi masyarakat lokal seperti menyanggar dan mambuang pasilih.}

Pembaharuan dalam berislam juga menjadi fokus Arsyad al-Banjarī, ia mengingatkan bahwa tradisi-tradisi yang menyimpang dalam Islam sangat berpotensi menciderai sendi-sendi keimanan. Salah satunya adalah bid'ah. Dalam menjelaskan bid'ah, ia mengutip beberapa hadis yang ditulis dalam kitab Tuhfat al-Rāghibin:

$$
\text { أهل البدعة شر الخلق والخلقية \}ورواه أبو نعيم }
$$

Artinya: Ahli bid'ah adalah sejahat-jahat makhluk dan tabi'at.

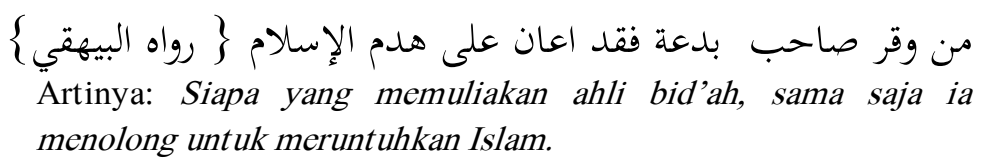

\footnotetext{
${ }^{34}$ Muhammad Arsyad al-Banjari, Tuhfat al-Raghibin, 21.

${ }^{35}$ Muhammad Arsyad al-Banjari, Tuhfat al-Raghibin, 21.
} 


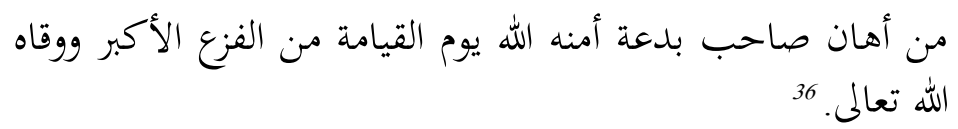

Artinya: Siapa yang menghinakan ahli bid'ah, Allah amankan ia dari huru hara dahsyatnya hari kiamat dan dipelihara Allah ia dari marabahaya.

Hadis menjadi sebuah 'senjata' buat Arsyad al-Banjari untuk melakukan pembaharuan akidah. Secara lebih lanjut ia memahami bid'ah dalam hadis ini adalah membuat suatu tradisi, pekerjaan ataupun kepercayaan dalam Islam yang tidak pernah dikerjakan oleh Nabi Muhammad saw. Namun Aryad al-Banjari tampaknya agak mioderat dalam memahami konsep bid'ah dalam Islam. Sebab menurutnya jika bid'ah itu mengandung nilai-nilai maslahat, maka bisa jadi bid'ah itu makruh ataupun mubah, dan bisa jadi bid'ah yang mashalat it u wajib dan sunah. Agar lebih jelas, ia membagi bid'ah itu menjadi lima bagian: (1) bid'ah wajib, contohnya seperti menafsirkan al-Qur'an, menjelaskan hadis, menulis kitab-kitab kaidah bahasa Arab, menulis kitab-kitab seperti ilmu farā'id, ushul fikih, ilmu hadis. (2) Bid'ah sunah seperti membahas tentang ilmu tasawuf. (3) Bid'ah yang mubah, seperti perbuatan bersalam-salaman sehabis shalat, memakan-makanan yang lezat, tinggal di rumah yang mewah. (4) Bid'ah yang makruh seperti menghiasi mesjid dan menghiasi mushaf al-Qur'an, (5) Bid'ah yang haram seperti mazhab Jabariyah, Qadariyah, Murjiah, dan Mujassimah. ${ }^{37}$

Resistensi kepercayaan dan praktek-praktek keagamaan pra-Islam di Kalimantan Selatan mendapat tantangan dari kalangan Islam skripturalis. Arsyad al-Banjari salah seorang ulama Banjar mendiskusikan tentang praktek kebudayaan pra-Islam dalam tuhfatnya tersebut. Selain menjelaskan tentang prinsip keimanan dan ketauhidan dalam Islam, kitab itu sekaligus juga mengecam kepercayaan dan praktek-praktek lokal yang tidak sesuai dengan prinsip-prinsip Islam. Termasuk di antara yang disebutkan al-Banjari sebagai bertentangan dengan Islam adalah praktek "menyanggar", persisnya "membuat ancak, memberi makanan (sesajian kepada datu-datu ghaib dan sebagainya yang lazim dilakukan sebagian umat Islam di sekitar daerah Kalimantan. ${ }^{38}$

${ }^{36}$ Hadis ini terdapat dalam kitab Musnad al-Shihāb dari riwayat sahabat ibn 'Umar. Lihat dalam Muhammad ibn Salāmah Abū 'Abd Allāh al-Qiḍā'ì, Musnad alShihāb (Beirut: Muassasat al-Risālah, 1986), 1/319.

${ }^{37}$ Muhammad Arsyad al-Banjari, Tuhfat al-Raghibin, 45-46.

38 Azyumardi Azra, "Interaksi dan Akomodasi Islam dengan Budaya Melayu Kalimantan", dalam Aswab Mahasin (ed.), Ruh Islam dalam Budaya Bangsa Aneka Budaya Nusantara (Jakarta: Yayasan Festival Istiqlal, 1996), 191. 
menurutnya tradisi semacam ini adalah tradisi yang masuk dalam kategori bid'ah ḍalālah, pelakunya wajib bertaubat dan para penguasa serta orang-orang yang berilmu wajib memberitahukannya. ${ }^{39}$

Menurut Arsyad al-Banjari, apabila upacara-upacara seperti menyanggar dan membuang pasilih itu dilakukan, maka hukumnya adalah sebagai berikut:

1. Bila diyakini, bahwa tidak tertolak bahaya kecuali melalui kedua upacara itu, maka hukumnya kafir.

2. Bila diyakini, bahwa tertolaknya bahaya adalah disebabkan karena kekuatan yang diciptakan Allah pada kedua upacara itu, maka hukumnya bid'ah lagi fasik tetapi tetap kafir.

3. Bila diyakini bahwa kedua upacara itu tidak memberi bekas dengan kekuasaan yang ada padanya atau kekuatan yang dijadikan Tuhan padanya tetapi Allah menolak bahaya itu dengan memberlakukan hukum kebiasaan dengan kedua upacara itu, tetapi hukumnya tidak kafir, tetapi bid'ah saja. Namun apabila diyakini kedua upacara itu halal atau tidak terlarang maka hukumnya kafir. ${ }^{40}$

Menyanggar dan membuang pasilih merupakan tradisi lama di mayarakat Banjar yang memberikan beberapa sesajen kepada ruh-ruh yang dianggap mempunyai kekuatan mistik. Menurut Arsyad al-Banjari tradisi ini adalah tradisi yang sesat menyesatkan. Setidaknya ada beberapa argumen yang diajukannya: (1) Kemungkaran karena tabzir (berlebih-lebihan), (2) mengikuti ajakan iblis, (3) Syirik, (4) mengadakan tradisi yang menyimpang dalam Islam. Ada sebuah hadis yang dikutip: ${ }^{41}$

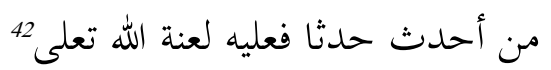

Artinya: Barang siapa mengadakan suatu pekerjaan yang tidak ada pada agama (kami), maka Allah akan melaknatnya.

39 Muhammad Arsyad al-Banjarì, Tuhfat al-Raghibīn fī Bayān Haquiqat İmān alMu'minin, 47.

${ }^{40}$ Muhammad Arsyad al-Banjari, Tuhfat al-Raghibin, 54.

${ }^{41}$ Muhammad Arsyad al-Banjari, Tuhfat al-Raghibin, 50-52.

${ }^{42}$ Hadis ini tidak disebutkan sumbernya dalam kitab tersebut. Sumber hadis ini terdapat dala kitab sunan Abü Dawud No. 4532 dengan redaski lengkapnya:

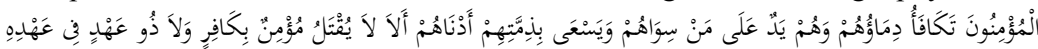

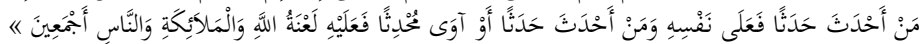

Lihat dalam, Abū Dawud, Sunan Abu Dawud (Beirut: Dār al-Kitāb al-'Arabīi, t.th), $4 / 303$. 
Bagi orang-orang yang sudah melakukan aktifitas semacam itu, maka Arsyad al-Banjari memberikan sebuah solusi agar sendi-sendi keimananannya bisa kokoh kembali dengan cara taubat. Taubat menjadi sebuah alternatif bagi yang ingin memurnikan akidahnya, hal ini tentunya diiringi dengan sebuah dalil dari hadis:

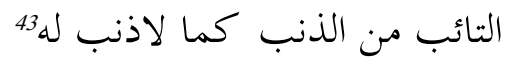

Artinya: orang yang bertaubat dari dosanya seperti orang yang tidak adalagi dosanya

Sedangkan kitab Sabī al-Muhtadī yang memang fokus terhadap hukum-hukum Islam tampaknya lebih banyak lagi memuat hadis-hadis Nabi saw. Dari riset yang dilakukan oleh Abdul Majid ditemukan bahwa Jumlah hadis yang dipakai dalam kitab ini sebanyak 223 hadis dengan keterangan 167

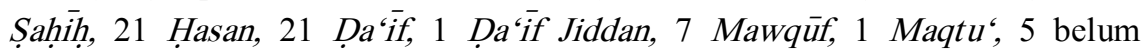
diketahui. $^{44}$ Namun setelah dibaca ulang hasil riset ini, Majid hanya mengungkapkan hadis-hadis yang ditulis dalam redaksi bahasa Arab saja. Padahal Arsyad al-Banjarī juga mengutip hadis-hadis yang dalam bentuk terjemahan bahasa Arab Melayunya saja. Sebagai kitab hukum Islam, ternyata kualitas-kualitas hadis dalam sabī al-muhtadin masih ada kualitasnya yang masih lemah.

Di dalam Sabīl al-Muhtadin, hadis-hadis yang dihadirkan dan dikutip berfungsi untuk diposisikan, setidaknya ada empat fungsi, yaitu:

1) Sebagai sumber hukum utama dari sebuah ibadah:

"(bermula asal) pada wajib sembahyang dahulu daripada ijma' beberapa ayat al-Qur'an seperti firman Allah ta'ala (wa aqīmū al-șalăt) artinya dan dirikan olehmu akan sembahyang, dan beberapa hadis seperti sabda nabi saw:

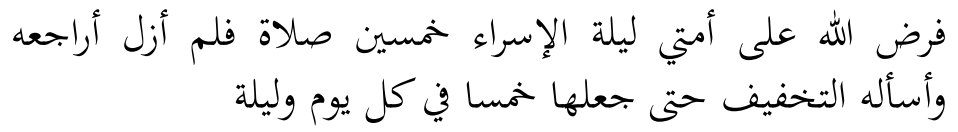

Artinya: telah memfardukan Allah ta'ala atas umatku pada malam isra lima puluh sembahyang, maka senantiasa aku kembali berulang-ulang kepada Allah swt, dan kumohonkan akan dia agar

\footnotetext{
${ }^{43}$ Hadis ini riwayat Ibn Majah, dan redaksi memang lengkap seperti itu. Lihat dalam Ibn Majah, Sunan ibn Majah (Beirut: Dār al-fikr, t.th), 2/1419.

44 Abdul Majid, "Telaah Kritis Terhadap Hadis-hadis Sabil al-Muhtadin" Tesis di Sekolah Pascasarjana Universitas Islam Negeri Syarif Hidayatullah Jakarta, 2007, 171.
} 
meringankan hingga dijadikan akan dia lima sembahyang di dalam tiap-tiap sehari dan semalam. Riwayat al-Bukhāri dan Muslim"."

2) Sebagai dalil suatu hukum perbuatan yang di istinbat dari hadis tersebut: “(dan wajib) pada puasa fardu berniat pada malam, yaitu barang yang antara masuk matahari dan terbit fajar, sama ia fardu ramadhan, atau nazar, atau kifarat, dan sama ada ia tunai, qadha, dan jikalau pada puasa anak-anak mumayyiz sekalipun, karena sabda Nabi saw:

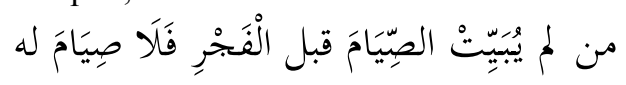

Artinya: Barangsiapa yang tiada bermalamkan niat puasa dahulu dari pada fajar, maka tiadalah baginya puasa" ${ }^{46}$

"(dan sunnah) dibacakan surah yāsin karena tersebut di dalam hadis yang shahih sabda Nabi saw "bacakanlah oleh kamu akan segala mereka yang hampir mati dari pada kamu surah yāsin. ${ }^{47}$ Dan tersebut pada setengah riwayat hadis yang lain sabda Nabi saw: tiada jua daripada orang yang sakit yang dibacakan surah yāsin lepaslah ia daripada dahaga ketika mati dan pada ketika dimasukkan ke dalam kubur". ${ }^{48}$

3) Sebagai dalil yang memberikan petunjuk teknis suatu ibadah "(pasal) pada menyatakan sunah yang dikerjakan di dalam puasa, (bermula) sunah makan sahur karena sabda Nabi saw:

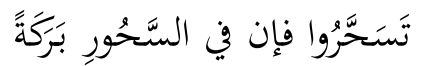

Artinya: Makan sahurlah kamu, karena bahwasanya pada makan sahur itu pada berkah. Riwayat al-Bukhārī dan Muslim". ${ }^{4}$

4) Sebagai dalil untuk fạ̣a'ìl al-a'māl (keutamaan beramal).

"(dan sunnah) berbanyak-banyak membaca surah al-kahfi pada hari jum'at dan pada malamnya karena tersebut di dalam hadis fadilat

${ }^{45}$ Muhammad Arsyad al-Banjari, Sabì al-Muhtadīn, 1/147.

${ }^{46}$ Muhammad Arsyad al-Banjari, Sabì al-Muhtadīn, 2/132.

47 Redaksi hadis ini secara lengkap terdapat dalam: Mụhammad ibn Hibbān, sahīh Ibn Hibbān (Beirut: Muassasat al-Risālah, 1993), 7/269. Hadis ini ditulis oleh ibn Ḥibbān dalam bab (al-Marị̣ wa ma yata 'llaq bih) dalam kitab (al-Janāiz)

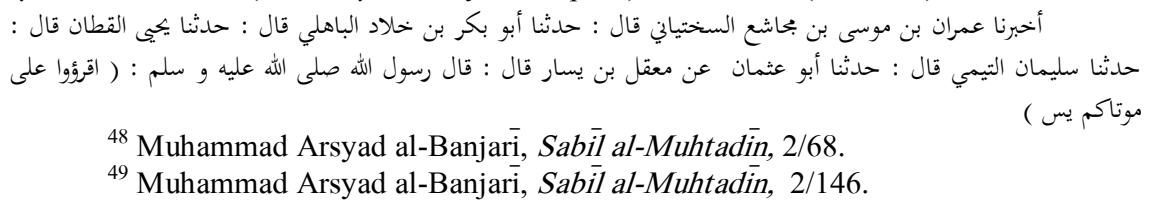


membaca pada hari jum'at dan malamnya. Sabda Nabi saw. Barangsiapa membaca Surah al-Kahfi pada hari jum'at dan malamnya, diterangilah baginya cahaya di antara dua Jum'at. ${ }^{50 "}$

\section{Generasi Kedua: Fase Pelestarian Jaringan}

Pada fase ini diwakili oleh dua ulama Banjar yang masih mempunyai darah keturunan dari Arsyad al-Banjari, yaitu Kasyful Anwar al-Banjarī (w. 1940 M) dan Muhammad Anang Sya'rani al-Banjari (w. 1969 M). Kasyful Anwar adalah sosok yang penting dalam perkembangan Islam di masyarakat Banjar, ia adalah pendiri dan sosok pembaharu dalam sistem pendidikan islam di Pondok Pesantren Darussalam Martapura.

Pada tahun $1313 \mathrm{H}$ atas inisiatif kakeknya H. Muhammad Arsyad dan neneknya $\mathrm{Hj}$. Aisyah, ia diberangkatkan ke Mekkah untuk menuntut ilmu. Dalam perjalanan tersebut, ayah dan ibu serta kakek dan neneknya ikut serta dalam perjalanan tersebut. Ayah dan ibunya wafat di Mekkah saat beliau menuntut ilmu. ${ }^{51}$ Dari fakta ini, tidak bisa dipungkiri bahwa peran keluarga dalam membentuk karakter, pribadi dan kapasitas intelektual sangat berpengaruh.

Ketika berada di Mekkah, ia belajar bahasa Arab dengan Syeikh Muhammad Amin al-Banjari (buyut dari Syeikh Arsyad al-Banjari) orang Martapura yang sudah lama menetap di sana guna bisa berkomunikasi dan belajar. Tampaknya komunitas pelajar banjar tetap bertahan dan terus bertambah jumlahnya pasca dibangun oleh Syeikh Arsyad. Pelajar Banjar yang aktif dalam kegiatan belajar dengan sistem halaqoh di Haramayn ini kemudian disebut dengan panggilan al-Banjari.

Selama di Mekkah ia banyak belajar dengan beberapa guru, di antaranya:

1. al-Sayyid Aḥmad ibn Abū Bakr Shațā (w. 1332 H) anak dari pengarang kitab I'ānah al-Ṭālibīin.

2. al-Ḥabīb Aḥmad ibn Hasan al-'Aț̣as (w. 1332 H).

3. al-Syeikh Muhammad 'Alìi ibn Ḥusayn al-Mālik̄i (w. 1367 H).

${ }^{50}$ Muhammad Arsyad al-Banjarì, Sabì al-Muhtadīn, 2/52. Redaksi hadis secara terdapat dalam riwayat al-Baihaqii: Ahmad ibn Ḥusayn ibn 'Ali al-Baihaqi, al-Sunan alSugrāa (Madinah: Maktabat al-Dār, 1989), 1/372. Hadis ini masuk dalam bab (Min Tahta 'alaihi al-Jum'at) dalam kitab (al-Șalat).

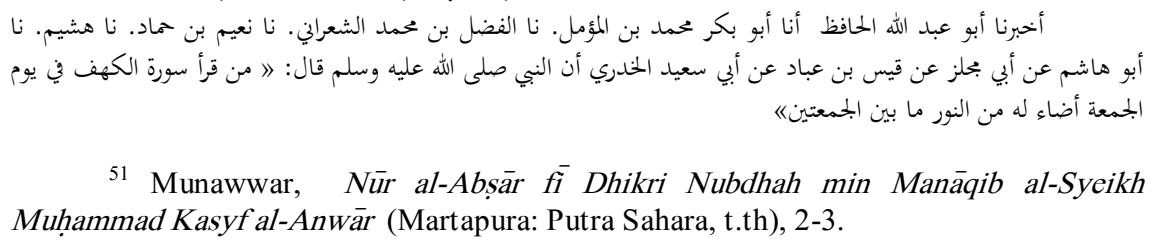

51 Munawwar, Nūr al-Abșār fī Dhikri Nubdhah min Manāqib al-Syeikh Muhammad Kasyf al-Anwār (Martapura: Putra Sahara, t.th), 2-3. 
4. Al-Syeikh Muhammad Șalih ibn Muhammad Bafadil (w. 1333 H)

5. Al-Syeikh Sayyid al-Yamani (w. $1352 \mathrm{H}$ )

Dalam bidang hadis, ia belajar dan mendapatkan ijazah dari dua gurunya: (1) al-Syeikh 'Umar ibn Hamdān (w. 1368 H) dan al-Sayyid Muhammad Amīn al-Kutbī $(1303 \mathrm{H})^{52}$.

Dalam catatan sanadnya, keilmuan 'Umar Hamdan terhubung dengan musnidah hadis wanita yang ada di Damaskus, al-Musnidah Zaynab bint alKamāl (w. 670 H). Menurut Riset yang dilakukan oleh Asma Sayeed tentang peranan perempuan dalam transmisi hadis, Zaynab merupakan transmitter yang sentral dalam perkembangan transmisi hadis di Damaskus. ${ }^{53}$

Sekembalinya ke tanah air, Kasyful Anwar termasuk salah satu ulama Banjar yang produktif dalam menghasilkan karya tulis. Salah satu karyanya di bidang hadis adalah penjelasan/komentar beliau terhadap kitab hadis-hadis dalam kitab Arba‘īn al-Nawawi yang diberi judul Tabyīn al-Rawī bi Sharh Arba'in al-Nawawi yang ditulis dengan menggunakan bahasa Arab Melayu.

Salah satu bukti bahwa pengaruh ulama Timur Tengah dalam proses pembentukan pemahaman keislaman sangat berpengaruh bisa dijumpai dalam kitab sharh hadis ini. Dalam tibyān al-rawī Pada hadis kelima "man aḥdatha fi amrinā hadhā minhu fahuwa raddun, (al-Bukhāri). Menurut Kasyful Anwar, hukum yang dapat ditarik dari hadis ini adalah bahwa segala sesuatu perbuatan yang tidak ada diperbuat pada zaman Rasulullah saw, dan tidak ada kaidah umum dari al-Quran, hadis, dan ijma', maka perbuatan tersebut dikategorikan sebagai tindakan yang bid'ah dalālalah. Seperti perbuatan salat tanpa bersuci. Adapun segala perbuatan yang tidak ada di zaman Nabi saw, akan tetapi perbuatan itu ditopang oleh dalil-dalil yang umum dari al-Qur'an dan hadis, maka perbuatan tersebut termasuk kategori bid'ah hasanah (baik). Seperti membangun tempat belajar, sekolah, menulis kitab-kitab. Kasyful Anwar berpegang dengan dalil al-Qur'an yang umum: wa ta'âwanu 'ala al-birr wa altaqwa (saling tolong menolonglah dalam hal kebaikan, Q.S. 5:2). Begitu pula dengan amaliyah membaca maulid Nabi saw, dan berdiri ketika bacaan maulid tersebut sampai pada kisah Nabi saw dilahirkan. Segala bentuk perbuatan ini dengan maksud menunjukkan kecintaan terhadap Nabi saw. Argumen ini diperkuat oleh hadis: là yu'minu ahadakum hatta akūna ahabba ilayh min waladihi wa wālidihi wa al-nās ajma 'ìn (al-Bukhārì). Artinya: "tidak sempurna

${ }^{52}$ Munawwar, Nür al-Abșār fì Dhikri Nubdhah, 6-7.

53 Asma Sayeed, "Women and Hadith Transmission Two Case Studies from Mamluk Damascus", Journal Studia Islamica No. 95 (2002), 72. Diakses dari http://www.jstor.org/stable/1596142 pada tanggal 11-6-2015. 
iman seseorang dari kamu, hingga ia lebih mencintaiku daripada anaknya, orang tuanya,dan sekalian manusia lainnya". 54

Tipologi bid'ah yang ditawarkan oleh Kasyful Anwar ini tampaknya berpegang dengan kaidah yang diajukan oleh al-Shāfi $\bar{i}$ yang mengatakan:

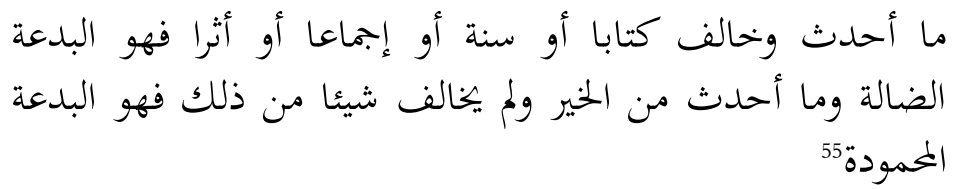

Artinya: Segala perbuatan yang bertentangan dengan al-Qur'an, hadis, ijma', dan athar maka termasuk dalam kategori bid'āh yang sesat, dan adapun segala perbuatan yang baik, tidak bertentangan dengan kaidah yang demikian itu, maka termasuk dalam kategori bid'ah yang baik.

Bid'ah menurut Kasyful Anwar adalah segala sesuatu tindakan yang tidak diperbuat oleh Rasulullah saw dan Sahabat. Definisi ini kiranya lebih luas dengan memasukkan perbuatan Sahabat sebagai acuan dalam bertindak, ketimbang dari definisi bid'ah umumnya yang hanya membatasi bid'ah dari segala perbuatan Rasulullah saja.

Tampaknya tipologi bid'ah yang ditawarkan oleh Kasyful Anwar ini sangat terpengaruh dengan gurunya al-Sayyid Aḥmad ibn Abū Bakr Shațā (w. $1332 \mathrm{H}$ ) anak dari pengarang kitab I‘ānah al-Ṭālibīn. Sebab kutipan dari alShāfi ‘’ tersebut terdapat dalam kitab I‘ānah al-Ṭălibīn. Juga demikian dengan pendahulunya Syeikh Arsyad al-Banjari yang membagi bid'ah itu kepada dua, yang sesat dan yang baik.

Ulama Banjar yang kedua pada fase pelestarian jaringan ini adalah Muhammad Anang Sya'rani Arif (w. 1969 M), di makamnya tertulis dengan jelas gelar 'al-mufassir' dan 'al-muhaddith'. Gelar ini tidak lepas dari kapasitas keilmuannya dalam kedua bidang tersebut.

Pada tahun 1350/1930 M, Anang Sya'rani bersama sepupunya KH Syarwani Abdan Bangil berangkat ke Mekkah untuk melaksanakan ibadah haji, sekaligus menetap di sana untuk belajar. Mainstream arah kiblat intelektual ulama Banjar condong ke Mekkah dan Madinah. Tradisi ini terus berlanjut sampai generasi selanjutnya, dari Haramayn untuk Banjar.

${ }^{54}$ Muhammad Kasyful Anwar al-Banjari, al-Tabyīn al-Rawi, 21-22.

55 Abū Bakr ibn Muhammad Shaṭa al-Dimyāțī, Hāshiyat I'ānah al-Ṭălibìn (Beirut: Dār al-Fikr, t.th), 1/313. 
Di antara guru Anang Sya'rani adalah (1) al-Sayyid Muhammad Amin al-Kutbī (1303 H), (2) al-Syeikh 'Umar ibn Hamdān (w. 1368 H), (3) Syeikh 'Alì ibn 'Abd Allah al-Banjarì.

Kepakarannya dalam bidang hadis bukan saja dilihat dari sanad hadis yang ia dapatkan, namun juga terlihat dari kapasitas keilmuannya yang mampu menghafal ribuan hadis lengkap dengan sanad dan matannya. Karya-karya yang terpublikasi hanya ada dua, dan kedua karya tulis tersebut membahas tentang kajian hadis. (1) Tanwir al-Ṭllāb fi Muștalạh al-Hadith, kitab ini dicetak Pondok Pesantren Darussalam dengan jumlah 36 halaman. Karya ini selesai ditulis pada hari kamis 14 șafar $1383 \mathrm{H}$. Tema yang dibahas adalah tentang ilmu hadis. ${ }^{56}$ Kitab ini bisa dikatakan hanya sebagai pengantar saja, sebab tidak ada pembahasan kritis tentang perdebatan ilmu hadis. Hal tersebut bisa dipahami, sebab kitab ini digunakan untuk pembelajaran santri-santri yang masih tingkat bawah. (2) Hidāyat al-Zamān fi Ahāìiht Akhīr al-Zamān. Kitab ini dicetak oleh Pondok Pesantren Darussalam yang jumlah halamannya ada 27. Kitab ini merupakan rekategorisasi hadis, Anang Sya'rani menghimpun hadis-hadis tentang prediksi atau tanda-tanda akhir zaman atau kiamat. Sumber hadisnya pun beragam, jumlah hadis dalam kitab Bukhāri dikutip ada 4 hadis, Muslim sebanyak 6 hadis, al-Tirmidhì 7 hadis, Abū Daud 1 hadis, al-Nasa' $\bar{i} 1$ hadis, Ibn Mājah 4 hadis, Imām Aḥmad 4 hadis, al-Baihaq̄i 2 hadis, Abū Nu'ain 2 hadis,

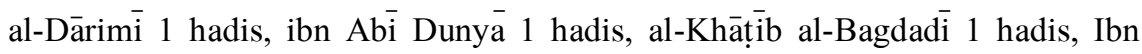
Mardawaih 1 hadis, al-Bazzar 1 hadis, al-Dailami 1 hadis, dan riwayat muttafaq 'alaih 1 hadis. Total hadis yang ada dikitab ini berjumlah 40 hadis. Adapun motif penulisan kitab ini dilandasi tujuan agar menjadi 'tadhkirah' atau pengingat bagi umat Islam tentang tanda-tanda hari kiamat. ${ }^{57}$

Corak pengkajian hadis yang dikembangkan oleh Sya'rani Arif al-Banjari ini setidaknya ada dua corak, corak kajian ilmu hadis, dan kajian arba' $\overline{\text { in }}$ hadis. Untuk kajian corak ilmu hadis, pembahasannya masih sama dengan mainstream ulama-ulama hadis sebelumnya, pun dengan tema yang disajikan. Kehadiran kitab ini sepertinya tidak lebih untuk sekedar bahan ajar yang disajikan dengan bentuk yang lebih sederhana untuk kalangan santri pondok pesantren Darussalam, Martapura, Kalimantan Selatan. Tanwir al-Ṭllāb mendiskusikan sub-sub bahasan dengan metode dialogis atau tanya jawab dengan bahasa Arab. Tipologi dan diskripsi tentang kualitas hadis yang ia tulis hampir sama saja

56 Muhammad Sya'rani 'Arif, Tanwīi al-Ṭullāb fi Muștalạ̣ al-Hadith (Martapura: Pondok Pesantren Darussalam, t. th), 1-36.

57 Muhammad Sya'rani 'Arif, Hidàyat al-Zamān fi Ahāidiht Akhìr al-Zamān (Martapura: Pondok Pesantren Darussalam, t. th), 1-26. 
dengan karya dari pakar-pakar mainstream dalam kajian hadis. Dalam arus sejarah muștalah hadis, Sya'rani Arif mendiskusikan beberapa fase penting, mulai dari al-Shäfi‘ $\bar{i}$ (w. 204) yang masih terintegrasi dengan kajian ushul fikih, kemudian ilmu ini berdiri secara mandiri ditandai dengan adanya karya dari alRamāhurmuzì (w.364) dengan kitabnya al- al-Muhaddith al-Fashī bayn al-Râw $\bar{i}$ wa al-Wa'i. Fase ketiga ditandai dengan adanya karya yang lebih komprehensif lagi pembahasannya, yaitu karya dari al-Hakīm al-Naisabūri (w. 405) dengan kitabnya ma'rifat 'ulüm al-hadith. Fase keempat pembahasan muștalah hadis lebih terperinci dan komprehensif dengan adanya karya dari al-Khāțib alBagdādi (w. $463 \mathrm{H}$ ) yang berjudul al-kifāyah. Pada fase kelima kajiannya sifatnya lebih melengkapi lagi dengan adanya karya dari ibn al-Șalạ̄ (w.643). Pada fase keenam diskursus kajiannya lebih fokus kepada pembahasan yang ringkas, intisari dari pembahasan-pembahasan yang sudah matang pada fasefase sebelumnya, salah satu kitab tipe seperti ini adalah Yạya ibn Sharaf alNawawi (w.642). Fase terakhir adalah kajian yang kontemporer sekarang ini. ${ }^{58}$ Menurut Saifuddin, tipologi arus sejarah yang ditawarkan oleh Sya'rani Arif ini tergolong baru yang tidak akan ditemukan dalam tipologi yang ditawarkan oleh beberapa pakar semisal al-Nawawī, ibn Kathir. ${ }^{59}$ Selebihnya pembahasan yang disajikan dalam diskusi karya Sya'rani Arif lebih hampir sama saja dengan pembahasan-pembahasan mainstream pakar hadis lainnya.

Sedangkan untuk corak arba'in hadis, pola ini sebenarnya sangat terpengaruh dengan tradisi intelektual ulama hadis Timur Tengah. Salah satu motif maraknya kajian arba'in disebabkan adanya landasan teologis dari sebuah hadis:

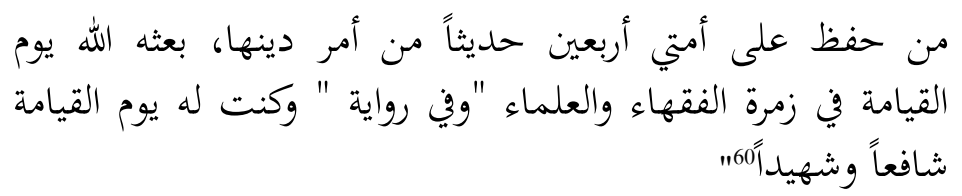

"Siapa yang menghafal empat puluh hadis dari umatku tentang permasalahan agama, maka Allah akan membangkitkannya pada hari kiamat nanti beserta para fuqaha dan ulama, dalam riwayat

${ }^{58}$ Muhammad Sya'rani Arif al-Banjari, Tanwìir al-Tullāb fì Mustalah al-Hadith (Martapura: Pondok Pesantren Darussalam, t.th), 8-9.

${ }^{59}$ Saifuddin, Peta Kajian Hadis Ulama Banjar, 230

${ }^{60}$ Salah satu sumber hadis ini terdapat dalam riwayat al-Baihaq $\bar{i}$ dari jalur sahabat Abū Hurayrah. Banyak pakar yang menyatakan hadis ini lemah, akan tetapi banyak ditemukan jalur riwayat yang meriwayatkan hadis ini. Lihat misalnya dalam: Aḥmad ibn Husayn al-Baihaqi, Shu'b al-Imān (Beirut: Dār al-Kutub, 1410 H), 2/270. 
lain, dan aku (muhammad) akan memberikan syafaat dan pertolongan pada hari kiamat nanti.

\section{Generasi Ketiga: Fase Pelestarian Jaringan}

Fase ini berlangsung pada tahun 1980-an sampai sekitar tahun 2000-an awal. Hubungan elite Banjar, dalam konteks ini adalah para pelajarnya yang tetap sedari awal konsisten menjadikan Timur Tengah sebagai destinasi keilmuan masih berlanjut. Keempat ulama yang menjadi objek dalam penelitian ini, Syukeri Unus, Abdul Wahid, Ahmad Fahmi Zamzam, dan Nurdir Marbu mempunyai guru hadis yang sangat otoritatif. Kendati berbeda 'angkatan' ketika belajarnya, mereka mempunyai guru-guru yang sama, yaitu Ismā'ì 'Uthmān Zayn al-Yamanī ( w. 1414 H), Muhammad Iwāạ al-Yamani, Yāsīn alFādānì (w. 1990M), Ḥasan Muhammad al-Mashat (w. 1399 H).

\section{Pengaruh dalam Bentuk Rekategorisasi Hadis}

Pertama adalah Syukeri Unus al-Banjari. Ia merupakan ulama lokal yang banyak belajar kepada ulama-ulama yang berada di Tanah Banjar saja. Berbeda dengan para pendahulunya yang memulai karier intelektualnya di Haramayn. Di antaranya gurunya adalah Syeikh Muhammad Anang Sya'rani 'Arif. Kendati demikian, ia pernah menetap beberapa bulan untuk duduk mengaji dan mengambil sanad keilmuan dengan ulama di Haramayn semisal Syeikh Muhammad Yāsīn al-Fādānī ( w. 1990 M), Syeikh Ismā'īl Zaini al-Yamāní, Syeikh Muḥammad Ḥasan Mashāt (Penulis kitab ilmu hadis raf al-asțār), Syeikh Mụ̣ammad 'Alwīi al-Mālikì, Syeikh 'Abd al-Karīm al-Banjarì al-Makki (w. $1422 \mathrm{H}$ ).

Dua karyanya di bidang hadis yang menjadi sumber dalam penelitian ini adalah; (1) Hadith al-'Arba'în fi al-'ilm, kitab yang dicetak majelis taklim Dār al-Shākirīn ini jumlah halamannya 48 halaman yang berisi 40 hadis tentang ilmu, dan ditambah dengan aneka doa di akhir pembahasan, dan beberapa sanad ijazah musalsal. Kitab ini selesai ditulis beliau pada tahun $1405 \mathrm{H}$. Sumber hadis dalam kitab ini pun beragam, 11 hadis dari riwayat al-Bukhāri, 6 hadis riwayat Muslim, 20 hadis riwayat al-Tirmidhi, 8 hadis riwayat ibn Mājah, 5 hadis riwayat Abū Dawud, 3 hadis riwayat Imām Rāzain, 2 hadis riwayat Imam al-Dailamí, dan 1 hadis masing-masing dari riwayat Imam al-Ṭabrāni, Imam Aḥmad, Imam al-Dārimī, al-Khātib, ibn 'Abd al-Bar, Abū Nua'īm. ${ }^{61}$ (2) Dalīi al-Ṭălibìn fì Ma'rifat Asma al-Hadith, kitab ini merupakan kajian ilmu hadis

61 Lihat dalam: Muhammad Syuker Unus, Hadith al-'Arba'in fí al-'ilm (Martapura, Dār al-Shākirīn, t. th), 1-26. 
yang diterbitkan pada tahun 1985. Bentuk pembahasan dalam kitab ini berupa "tanya-jawab" yang argumen jawabannya tersebut diperkuat oleh syair-syair "al-Manzūmat al-Bayquniyyah" karya Imām al-Baiqūni (w. 1080 H). Sehingga bisa dikatakan kitab hadis ini merupakan penjelasan singkat tingkat matanmatan tersebut. ${ }^{62}$ Dalam pembahasan terakhirnya, pengaruh ulama Timur Tengah sangat kental sekali, yaitu cara membaca hadis yang dipelajari dari Yāsin al-Fādāni. Awal kalimat yang diucapkan awal dalam pembacaan hadis, adalah:

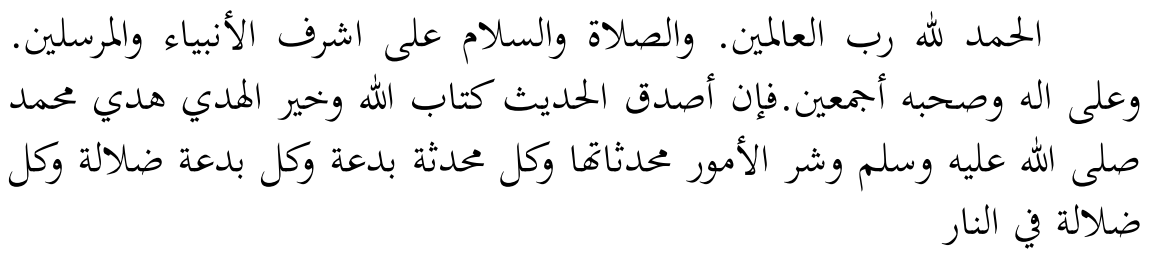

Muqaddimah ini terasa sangat penting dalam pembelajaran hadis di halaqoh ulama Banjar. Redaksi tersebut ditambah lagi dengan ungkapan: “wa bisanadihi al-muttasil ila al-imām”, yang menunjukkan bahwa orang yang membaca hadis tersebut mempunyai sanad yang terhubung dengan mukharrij hadis.

\section{Penutup}

Dari uraian di atas ditemukan bahwa dinamika intelektual ulama Banjar dalam kajian hadis begitu pesat perkembangannya. Jika selama ini kajian-kajian corak keislaman di masyarakat Banjar hanya berkisar pada perkembangan pola kajian tawasuf, fikih, dah tauhid, maka penelitian ini hadir sebagai jawaban bahwa tradisi intelektual mereka berkembang secara struktural dan kultrural. Perkembangan tersebut dapat dilihat dari beberapa indikasi yang telah ditemukan.

Temuan ini berangkat dari pembacaan yang komprehensif terhadap karya-karya hadis yang terpublikasi dari karya ulama Banjar, baik yang dicetak secara lokal, maupun yang masih berbentuk naskah-naskah pribadi. Perkembangan tradisi intelektual ini tidak bisa dilepaskan dari peran para ulama Timur Tengah yang membentuk pola pikir dan corak keislaman ulama Banjar.

Dalam kasusnya penelitian ini adalah salah satu bentuk penelitian yang mengekplorasi khazanah intelektual Islam karya ulama Indonesia, khsususnya dalam kajian hadis. Penelitian ini masih sangat terbatas pada aspek transmisi hadis dan pola jaringan hadis ulama Banjar. Hal ini tentunya memberikan

${ }^{62}$ Lihat dalam: Muhammad Syuker Unus, Dalì al-Tălibìn fì Ma rifat Asma alHadith (Martapura: t.p, t.th), 1-35. 
peluang kepada para peneliti lain agar bisa mengkaji karya-karya hadis mereka dengan pendekatan disiplin ilmu yang berbeda. Kemudian juga, penelitian ini bisa menjadi inspirasi bagi peneliti lain yang konsen dibidang hadis untuk mengeksplor karya-karya lokal ulama Indonesia. Baik yang masih berupa manuskrip atau yang sudah dicetak.

\section{Daftar Pustaka}

Abdullah, Wan Mohd Shagir. Syeikh Muhammad Arsyad al-Banjari Pengarang Sabìl al-Muhtadīn. Kuala Lumpur: Khazanah Fathaniyah, 1990.

Abū Dawud, Sunan Abu Dawud. Beirut: Dār al-Kitāb al-'Arabī, t.th.

Azra, Azyumardi. "Interaksi dan Akomodasi Islam dengan Budaya Melayu Kalimantan", dalam Aswab Mahasin (ed.), Ruh Islam dalam Budaya Bangsa Aneka Budaya Nusantara. Jakarta: Yayasan Festival Istiqlal, 1996.

--------. Historiografi Islam Kontemporer, Wacana Aktualitas dan Aktor Sejarah. Jakarta: Gramedia Pustaka Utama, 2002.

--------. Jaringan Ulama Timur Tengah dan Kepulauan Nusantara Abad XVII \& XVIII: Akar Pembaharuan Islam Indonesia. Jakarta: Kencana, 2007.

-------. Renaisans Islam Asia Tenggara: Sejarah Wacana dan Kekuasaan. Bandung: PT Remaja Rosda Karya, 1999.

al-Baihaqī, Ahmad ibn Husayn ibn 'Ali. al-Sunan al-Sugrā (Madinah:

Maktabat al-Dār, 1989), vol. 1, 372

Daudi, Abu. Maulana Syeikh Muhammad Arsyad al-Banjarī (Tuan Haji Besar).

Martapura: Yayasan Islam dalam Pagar, 2003.

al-Dimyāțì, Abū Bakr ibn Muhammad Shața. Hāshiyat I'ānah al-Ṭālibīn. Beirut: Dār al-Fikr, t.th.

Ibn Hibbān, Mụhammad. șahīh Ibn Hibbān. Beirut: Muassasat al-Risālah, 1993. Maarif, Ahmad Syafii. Islam dalam Bingkai Keindonesian dan Kemanusiaan. Bandung: Mizan, 2015.

al-Makkī, 'Abd Allah ibn Sālim. al-Imdād fī Ma'rifat 'Uluw al-Hadith. Riyad: Dār al-Tauhīi, t.th.

Makki, Ahmad. Profil dan Kinerja Anak Banua: Apa \& Siapa dari Utara. Banjarmasin: MUI, 2011.

Moleong, Lexy J. Metodologi Penelitian Kualitatif. Bandung: PT Remaja Rosda Karya, 2014. 
Mụ̣ammad, Riḍo ibn. Musnid al-Hijāz. Makalah di Universitas King Abdul Aziz Jeddah, Fakultas Adab dan Humaniora.

Munawwar, Nūr al-Abșār fī Dhikri Nubdhah min Manāqib al-Syeikh Muhammad Kasyf al-Anwār. Martapura: Putra Sahara, t.th.

Muṭallib, Rif'at Fauzī 'Abd. Manāhij al-Muhaddithīn al-Usus wa al-Tatbīiq. Kairo: Dār al-Salām, 2008.

Qị̣̄à', Muhammad ibn Salāmah Abū 'Abd Allāh. Musnad al-Shihāb. Beirut: Muassasat al-Risālah, 1986.

Saifuddin. Arus Tradisi Tadwin Hadis dan Historigrafi Islam: Kajian Lintas Aliran. Yogyakarta: Pustaka Pelajar, 2011.

-------, Peta Kajian Hadis Ulama Banjar. Banjarmasin: Antasari Pres, 2013.

al-Zahrānī, Muhammad ibn Maṭar. Tadwīn al-Sunnah al-Nabawiyah Nash'atuhu wa Tatawwuruhu min al-Qarn al-Awwal ilà Nihāyah al-Qarn al-Täsi' alHijri. Madinah: Dār al-Khuḍayrī, 1998.

\section{Jurnal}

Amin, Kamaruddin. "Nāṣiruddīn al-Albānī on Muslim's Șahīḥ: A Critical Study of His Method" Journal Islamic Law and Society, Vol. 11, No. 2 (2004), 149-176. Diunduh pada tanggal 10 Juli 2015 melalui http://www.jstor.org/stable/3399302.

Dickinson, Eerik. "Ibn al-Șalāh al-Shahrazūrī and the Isnād", Journal of the American Oriental Society, Vo. 122, No. 3 (Jul,-Sep., 2002), 481-505. Diakses melalui http://www.jstor.org/stable/3087517 pada tanggal 15 September 2015.

Fatkhi, Rifqi Muhammad. "Hadith dalam Hegemoni Fiqh: Membandingkan Sahịh Ibn Hibbān dan Sunan Ibn Majah", Journal of Qur'ān and Hadith Studies, Vol. 1, No.1. (2011). 145-179.

Melchert, Christopher. "Bukhāri and Early Hadith Criticism", Journal of the America Oriental Society, Vol. 121, No.1 (2001), 7-19. http://www.jstor.org/stable/606725, diakses pada tanggal 10-6-2015.

Mubarak, Ahmad Taufik. "Tuan Guru Haji Kasyful Anwar dan Kiprahnya di Pondok Pesantren Darussalam Martapura", Jurnal Studi Islam Kalimantan, Vol. 8, No. 2 (2009), 151-166.

Mujiburrahman, "Islamic Theological Text and Context in Banjarese Society: An Overview of the Existing Studies," Southeas Asian Studies (SEAS), Voi. 3, No. 3 (2014), 611-641. 
Rusydi, M. "Ideologi dan Epistimologi Kitab Tuhfah al-Rāghibīn Karya Muhammad Arshad al-Banjari”, Jurnal Islamica, Vol. 8, No. 2 (Maret, 2014), 475-502.

Saifuddin, Dzikri Nirwana, Bashori, "Peta Kajian Hadis Ulama Banjar" Jurnal al-Tashwir, Vol.1, No, 2 (2003). 17-29.

Sayeed, Asma. "Women and Hadith Transmission Two C €ase Studies from Mamluk Damascus”, Journal Studia Islamica No. 95 (2002), 71-94. Diakses dari http://www.jstor.org/stable/1596142 pada tanggal 11-6-2015.

Shaukat, Jamila. "Classification of Hadīth Literature”, Islamic Studies, Vol. 24. No. 3 (1985), 357-375. Diunduh pada tanggal pada 10 Juli 2015 melalui http://www.jstor.org/stable/20839730.

. "The Isnād in Hadith Literature", Journal Islamic Studies, Vol. 24, No.

4 (Winter 1985), 445-454, diakses pada tanggal 5 September 2015 melalui http://www.jstor.org/stable/20839742.

Su'aidi, Hasan. "Jaringan Ulama Hadis Indonesia”, Jurnal Penelitian, Vol.5, No.2 (2008). 1-16.

Voll, John O. “ 'Abd Allah ibn Salim al-Basri and 18th Century Hadith Scholarship", Journal Die Welt des Islams, New Series, Vol. 42, Issue 3, Arabic Literature and IslamicScholarship in the 17th/18th Century: Topics and Biographies (2002), 356-372.. Diakses melalui http//www.jstor.org/stable/1571419 pada tanggal 3 Maret 2016.

\section{Disertasi}

Muhajirin, "Transmisi Hadis di Nusantara: Peran Ulama Hadis Muhammad Mahfūdz al-Tarmasī,” Disertasi SPs UIN Jakarta, 2009.

\section{Karya Ulama al-Banjari}

al-Banjari, Ahmad Fahmi Zamzam, 40 Hadis Akhak Mulia . Malaysia: Khazanah Banjariah, 2004.

al-Banjari, Ahmad Fahmi Zamzam, 40 Hadis Kelebihan Ilmu dan Ulama. Banjarbaru: Pondok Pesantren Yasin, 2004.

al-Banjari, Ahmad Fahmi Zamzam, 40 Hadis Penawar Hati. Banjarbaru: Pondok Pesantren Yasin, 2007.

al-Banjarī, Ahmad Fahmi Zamzam, 40 Hadis Peristiwa Akhir Zaman. Banjarbaru: Pondok Pesantren Yasin, 2010.

al-Banjarī, Ahmad Fahmi Zamzam, al-Awā'il al-Zamzamiyyah al-Banjariyyah. Banjarbaru: Pondok Pesantren Yasin, 2011. 
al-Banjari, Ahmad Fahmi Zamzam. 3 Hadis Musalsal. Banjarbaru: Pondok Pesantren Yasin, 2015.

al-Banjarī, Abdul Wahid. Tadhkirah al-Lisān min al-Ahāäith al-Mawḍu'iyyah 'Ala Sayyid al-Bashar. Barabai: Pondok Pesantren Dār al-Hidāyah, 2012. al-Banjarī, Muhammad Kasyf al-Anwar. Tabyīn al-Rawī bi Sharh Arba'īn alNawawì. Martapura: Dār al-Shakirin, t. th.

al-Banjari, Muhammad Arsyad, Sabìi al-Muhtadin litafaqquh Fì Amr al-Din. Singapura: al-Haramayn, t.th.

al-Banjarī, Muhammad Arsyad. Tuhfah al-Raghibīn fī Bayān Haqīqat İmān alMu'minin. Martapura: Dār al-Shākirin, t.th.

al-Banjarì, Muhammad Nūr al-din Marbū al-Makkī, Adab al-Mushā fahah. t.tp: Majlis al-Banjari $\overline{\text { li }}$ Tafaqquh fi al-Dín, 1996.

al-Banjarì, Muhammad Sya'rani 'Arif, Hidāyat al-Zamān fi Ahàdīht Akhīr alZamān. Martapura: Pondok Pesantren Darussalam, t. th.

al-Banjarī, Muhammad Sya'rani 'Arif. Tanwīr al-Ṭullāb fi Muștalaḥ al-Hadith. Martapura: Pondok Pesantren Darussalam, t. th.

al-Banjarī, Muhammad Syuker Unus, Dalīi al-Ṭălibīn fì Ma'rifat Asma alHadith. Martapura: t.p, t.th.

al-Banjari, Muhammad Syuker Unus. Hadith al-'Arba'in fì al-'ilm. Martapura, Dār al-Shākirīn, t. th.

al-Banjarìi, Muhammad Syukeri Unus. Ni 'mat al-Juwād li Ṭălib al-Isnād li kutub al-Sittah. Martapura: Dār al-Shākirīn, 